\title{
RENAL GLYCOSURIA *
}

\author{
D. S. LEWIS, M.D. \\ MONTREAL, CANADA
}

There are four cardinal points in the diagnosis of this interesting anomaly: (a) a glycosuria without hyperglycemia; (b) little, if any, relationship between the carbohydrate intake and the amount of glucose excreted in the urine; (c) the absence of the signs and symptoms characteristic of diabetes mellitus, and (d) a long period of observation during which the patient shows no tendency to develop diabetes mellitus. Joslin $^{1}$ lays particular stress on the last criterion, which is the most difficult to carry out. A critical review of the literature is made. by Goto, ${ }^{2}$ Bailey, ${ }^{3}$ Strouse ${ }^{4}$ and Lewis and Mosenthal. ${ }^{5}$ When preparing data connected with the report in 1915, Lewis and Mosenthal found less than ten cases which were described in sufficient detail to warrant their acceptance as instances of true renal glycosuria, but since that time at least nine other cases ${ }^{6}$ have been noted. With the more careful observations of the blood sugar this depression of the "leak point" for glucose is being recognized with greater frequency.

In this paper a further note is recorded on the case reported in $1915^{5}$ and studies of two other instances observed in the metabolism clinic of the Royal Victoria Hospital are presented in some detail. The clinical findings in the first patient may now be said to fulfill all four - requirements as he has been observed for a period of six years; the second and third cases which have been observed for twelve and fifteen months, respectively, can be regarded as answering the first three tests, but a final decision will not be possible without a further period of observation.

Methods Employed.-Sugar identified as glucose, by fermentation; osazone crystals; and synchronous determinations of the amount of sugar by polariscopic and copper reduction methods. Urinary sugar: Benedict's standard quantitative methods. Blood sugar: LewisBenedict method, unless otherwise stated in the text.

* From the Metabolism Clinic of the Royal Victoria Hospital.

1. Joslin, E.: Treatment of Diabetes Mellitus, Philadelphia, 1917, p. 64.

2. Goto, K.: Alimentary Renal Glycosuria, Arch. Int. Med. 22:96 (July) 1918.

3. Bailey, C. V.: Renal Diabetes, Am. J. M. Sc. 157:221, 1919.

4. Strouse, S.: Renal Glycosuria, Arch. Int. Med. 26:768 (Dec.) 1920.

5. Lewis, D. S., and Mosenthal, H. O.: Renal Diabetes, Bull. Johns Hopkins Hosp. 27:133, 1916.

6. Beard. H., and Grave, F.: Renal glycosuria, Arch. Int. Med. 21:705 (June) 1918. Allen, F. M.; Wishart, M. B., and Smith, L. M.: Three Cases of "Renal Glycosuria," Arch. Int. Med. 24:523 (Nov.) 1919. Paullin, J. E.: Renal Glycosuria, J. A. M. A. 75:214 (July 24) 1920. Marsh, P.: Renal Glycosuria, Arch. Int. Med. 28:54 (July) 1921. 


\section{REPORT OF CASES}

CASE 1.-W. P. W. (medical No. 34774), was first studied in September, 1915. On admission to the Johns Hopkins Hospital his urine contained 2.06 per cent. sugar, and the daily output averaged $25 \mathrm{gm}$., with a blood sugar ranging from 0.08 to 0.11 per cent. He gave a normal curve following the ingestion of $100 \mathrm{gm}$. glucose. Further studies by Mosenthal, in 1916, confirmed the findings. In August, 1921, the patient reported that he had continued in excellent health since his discharge from the hospital. He had gained 12 pounds in weight; he had survived a severe "flu" infection, and was taking a full and unrestricted diet. His urine still contained about 2 per cent. sugar, but he had no thirst, polyuria, or any other symptoms of diabetes mellitus.

The following data of recent studies on this individual have been supplied by Dr. F. M. Hanes of Winston-Salem, N. C., and prove that his condition has shown no essential change. The diagnosis made in 1915 has been verified by the subsequent course of the case.

The functional condition of the kidney has attracted considerable attention in renal glycosuria. Klemperer ${ }^{7}$ in his first description of what he termed "renal diabetes," stated that the sugar always disappeared from the urine with the onset of a nephritis. On the other

TABle 1.-Response of Blood Sugar to 132 Gm. Glucose

\begin{tabular}{|c|c|c|}
\hline June 8, 1921 & Blood Sugar, per Cent. & Remarks \\
\hline 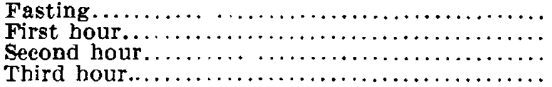 & $\begin{array}{l}0.09 \\
0.15 \\
0.12 \\
0.10\end{array}$ & After 24 hours fasting \\
\hline
\end{tabular}

The urine passed during the twelve hours preceding the test contained 3.5 per cent. sugar (Benedict).

hand, Lüthje, ${ }^{8}$ Tachau $^{9}$ and Naunyn ${ }^{10}$ suggested a direct causal relationship between the nephritis and the glycosuria, and the first two gave examples of proved renal glycosuria in which the onset seemed to be associated with the appearance of a nephritis. Frank ${ }^{11}$ has described a glycosuria following the toxic nephritis produced by mercury, uranium, chromium and cantharadin, but there has been little evidence of severe kidney disease in a majority of the reported cases. Bailey ${ }^{3}$ described one case of severe parenchymatous nephritis, with a renal glycosuria. The blood sugar was comparatively high, and after $75 \mathrm{gm}$. glucose it rose to 0.4 per cent., returning to the fasting level

7. Klemperer, G.: Ueber regulatorische Glykosurie und renalen Diabetes, Berl. klin. Wchnschr. 33:571, 1896.

8. Lüthje, H.: Beitrag zur Frage des renalen Diabetes, München. med. Wchnschr. 38: 1471, 1901.

9. Tachau. H.: Beitrag zum Studium des Nierendiabetes, Deutsch. Arch. f. klin. Med. 104: $448,1911$.

10. Naunyn, B.: Der Diabetes Mellitus, Wien., 1906, p. 136.

11. Frank. E.: Ueber experimentelle u. klinische Glykosurien renalen Ursprungs. Arch. f. exper. Path. u. Pharmakol. 72:387, 1913. 
six hours after the meal. This, he states, is a type of curve often seen in nondiabetic cases of nephritis. In this patient the sugar output was remarkably constant, and there was no sign of a true diabetes. Mosenthal and Lewis ${ }^{12}$ also report a case of arteriosclerosis and primary contracted kidney, in which a glycosuria appeared while under observation. This patient excreted 22.per cent. of phthalein in two hours, and his blood urea was $0.749 \mathrm{gm}$. per liter. With a fasting blood sugar of 0.10 per cent., the urine contained 0.13 per cent. sugar, and after the ingestion of $100 \mathrm{gm}$. glucose the blood sugar rose to 0.26 per cent. in 90 minutes, and returned to the fasting level at the end of three hours.

The following cases are examples of this type of renal glycosuria.

CAsf 2.-May 5, 1920, T. C., (metabolism No. 50), Chinese boy, aged 18 .

History.-About four weeks before admission he had a chill and fever. He passed very little urine. His legs began to swell, and he had to stop work. The swelling gradually spread to his trunk, arms and face. No further history was obtainable. He was admitted to hospital May 9 and transferred to the Metabolism Clinic May 21.

.Physical Examination.-Temperature, 98; pulse, 70; respiration, 20 (on admission). Patient was an adult Chinese of about stated age. He lay comfortably in bed. There was marked general anasarca; pupils equal and active; teeth in fairly good condition; tonsils not enlarged; tongue coated; no general glandular enlargement; thyroid not enlarged; no signs of hyperthyroidism. The chest wall was edematous. There was a bilateral hydrothorax and many moist râles were heard over botil lungs. The heart was regular in rhythm, and extended $7 \mathrm{~cm}$. to the left of the midline. The sounds were well heard. There were no murmurs or accentuations. The vessel walls were not thickened. Blood pressure: $110 / 65$. The abdomen was tense; the walls were edematous; there was a marked ascites; the liver and spleen were not palpable. The genitalia were much swollen, there was no urethral discharge. The reflexes were active. The eyegrounds were normal.

Urine: Acid; cloudy; specific gravity, 1.026; albumin, $20 \mathrm{gm}$. per liter; no sugar. Microscopic Examination: Granular, hyalin and fatty casts. White blood celts and an occasional red blood cell.

Tests of Kidney Function.-Blood urea, $0.585 \mathrm{gm}$. per liter; plasma chlorids, $5.65 \mathrm{gm}$. per liter; phthalein tests, 8 per cent. in two hours.

Blood: Wassermann test negative. Red blood cells, 5,910,000; white blood cells, 5,600; hemoglobin, 85 per cent. (Talquist).

Diagnosis.-Chronic diffuse nephritis; general anasarca.

Diary.-In view of the severity of the nephritis the patient was kept in bed on a salt-poor diet, with an average daily carbohydrate intake of $125 \mathrm{gm}$. His condition gradually improved, and he lost 16 kilos in weight, but with an increased diet his edema returned and his general condition became much worse. At this time an estimation of the blood proteins showed a globulin-albumin ratio of $3.61: 1.30$, which is a complete reversal of the usual proportions. In view of Epstein's ${ }^{13}$ reports, the diet was changed September 10 , to one with

12. Mosenthal, H. O., and Lewis, D. S.: The D:N Ratio in Dialsetes Mellitus, Bull. Johns Hopkins Hosp. 28:187, 1917.

13. Epstein, A. A.: Oedema in Chronic Nephritis, Am. J. M. Sc. 154:638 (Nov.) 1917. 
low fat and relatively high protein values. There was little change in the water balance, but the total nonprotein nitrogen of the blood mounted from $40 \mathrm{mg}$. per hundred c.c. to $89 \mathrm{mg}$. per hundred c.c. in six days, and the diet was discontinued soon afterward. Suddenly, September 22, a glycosuria appeared. The first day the output was $6.99 \mathrm{gm}$.; the next day it was $7.39 \mathrm{gm}$., and for the succeeding eight months sugar was absent in only five twenty-four-hour specimens, and in individual specimens of six other days. During this entire period the output has never exceeded $16.8 \mathrm{gm}$., and it has been between 5 and $10 \mathrm{gm} .151$ times in a total of 230 determinations (Table 2), while the concentration in the urine has been from 0.5 to 0.75 per cent. in two of every three examinations. In other words, the output and concentration have shown a high degree of constancy.

TABLE 2.-Range of Concentration and Tótal Excretion of Sugar in Urine

\begin{tabular}{cccccc}
\hline \hline $\begin{array}{c}\text { Concentration in } \\
\text { Urine, per Cent. }\end{array}$ & $\begin{array}{c}\text { Number of } \\
\text { Analyses }\end{array}$ & $\begin{array}{c}\text { Per Cent. of } \\
\text { Total No. }\end{array}$ & $\begin{array}{c}\text { Output in Gm. } \\
\text { per Day }\end{array}$ & $\begin{array}{c}\text { Number of } \\
\text { Analyses }\end{array}$ & $\begin{array}{c}\text { Per Cent. of } \\
\text { Total No. }\end{array}$ \\
Above 0.75 & 38 & 16.5 & Above 10.0 & 38 & 16.5 \\
0.75- 0.50. & 151 & 65.7 & $10.0-5.0$ & 151 & 65.7 \\
Below 0.50 & 41 & 17.8 & Below 5.0 & 41 & 17.8 \\
\hline
\end{tabular}

TABLE 3.-Independence of Carbohydrate Intake and OUtput

\begin{tabular}{|c|c|c|c|c|c|}
\hline \multirow[b]{2}{*}{ Date, 1920} & \multicolumn{3}{|c|}{ Diet } & \multicolumn{2}{|c|}{ Sugar in Urine } \\
\hline & Protein & Fat & Carbohydrate & Per Cent: & Gm. \\
\hline 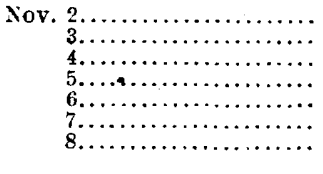 & $\begin{array}{l}41 \\
49 \\
39 \\
20 \\
46 \\
46 \\
46\end{array}$ & $\begin{array}{l}42 \\
57 \\
39 \\
21 \\
53 \\
53 \\
53\end{array}$ & $\begin{array}{r}174 \\
209 \\
144 \\
87 \\
204 \\
204 \\
204\end{array}$ & $\begin{array}{r}0.86 \\
0.51 \\
0.52 \\
0.60 \\
0.43 \\
0.40 \\
\text { D. } 0.28 \\
\text { N. } 0.00\end{array}$ & $\begin{array}{l}6.45 \\
3.82 \\
3.74 \\
2.70 \\
2.79 \\
6.68 \\
1.12 \\
0.00\end{array}$ \\
\hline 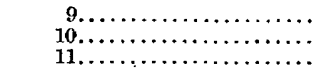 & $\begin{array}{l}46 \\
28 \\
54\end{array}$ & $\begin{array}{l}53 \\
30 \\
61\end{array}$ & $\begin{array}{l}204 \\
138 \\
135\end{array}$ & $\begin{array}{l}0.51 \\
0.65 \\
0.43\end{array}$ & $\begin{array}{l}5.71 \\
6.82 \\
3.01\end{array}$ \\
\hline
\end{tabular}

D., day specimen; N., night specimen.

Again, the total output of glucose seems to be independent of the carbohydrate intake, the higher rates of excretion often being associated with the lower diets and vice versa. Table 3 will serve to illustrate the independence of intake and output.

Similarly, his excretion varies from 0 to $8.16 \mathrm{gm}$. during the period from November 16 to December 16 with an unchanged diet which contained protein, $50 \mathrm{gm}$; fat, $57 \mathrm{gm}$., and carbohydrate, $234 \mathrm{gm}$. Throughout the period of observation the changes in the output are featured by their sudden onset and disappearance. In Table 3 the output is $6.68 \mathrm{gm}$. one day, $1.12 \mathrm{gm}$. the next day, then sugar free for twelve hours, and on the following day is reestablished at its old level of $5.71 \mathrm{gm}$. On the other hand, during any particular day the rate of 
excretion from hour to hour seems to be very constant. Two hourly collections are presented in Table 4 , and show a maximum variation in concentration of only 0.16 per cent., and an hourly output from 0.50 to $0.36 \mathrm{gm}$.

In September, 1921, he was studied again, and at this time he was fasted for three days before becoming sugar free. On a gradually increasing carbohydrate diet traces of sugar reappeared with $30 \mathrm{gm}$. carbohydrate given as green vegetables, and a measurable quantity ( 0.18 per cent.), with a diet containing $40 \mathrm{gm}$. of carbohydrate in the form of potato.

A glucose curve was also carried through with the following results, which are quite typical of those seen in nondiabetic cases of nephritis. There is a relatively slow rise to the maximum ( 0.241 per cent.), at one

TABLE 4.--Rate of Sugar Excretion from Hour to Hour

March 7, 1921. Diet: Protein, $70 \mathrm{gm}$; fat, $81 \mathrm{gm}$.; carbohydrate, $250 \mathrm{gm}$.

\begin{tabular}{|c|c|c|c|c|c|}
\hline Time & Volume in C.c. & Spec. Gr. & Per Cent. & $\mathrm{Gm}$. & Gm. per Hour \\
\hline 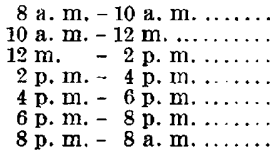 & $\begin{array}{l}116 \\
138 \\
152 \\
142 \\
170 \\
140 \\
775\end{array}$ & $\begin{array}{l}1.022 \\
1.020 \\
1.021 \\
1.022 \\
1.020 \\
1.021 \\
1.019\end{array}$ & $\begin{array}{l}0.71 \\
0.63 \\
0.66 \\
0.69 \\
0.56 \\
0.67 \\
0.55\end{array}$ & $\begin{array}{l}0.82 \\
0.87 \\
1.00 \\
0.98 \\
0.95 \\
0.94 \\
4.26\end{array}$ & $\begin{array}{l}0.41 \\
0.43 \\
0.50 \\
0.49 \\
0.47 \\
0.47 \\
0.36\end{array}$ \\
\hline Total.............. & 1,633 & & & $9.8 ?$ & \\
\hline
\end{tabular}

TABle .5.-Response of Blood and Urine to 100 Gm. Glucose

\begin{tabular}{|c|c|c|c|c|c|c|c|}
\hline \multirow{9}{*}{$\begin{array}{c}\text { Time } \\
9: 00 \text { a. m. } \\
9: 30 \text { a. m. } \\
10: 15 \text { a. m. } \\
10: 30 \text { a. m. } \\
11: 00 \text { a. m. } \\
11: 30 \text { a. m. } \\
12: 30 \text { p. } \mathrm{m} \text {. } \\
2: 30 \text { p. } \mathrm{m} \text {. }\end{array}$} & \multirow{2}{*}{$\begin{array}{l}\text { Blood } \\
\text { Sugar* }\end{array}$} & \multicolumn{2}{|c|}{ - } & \multicolumn{2}{|l|}{ Urine } & \multirow{3}{*}{ Gm. per Hr. } & \multirow{6}{*}{$\begin{array}{l}\text { Remarks } \\
100 \mathrm{gm} \text { glucose } \\
\text { in } 200 \text { c.c. of } \\
\text { lemonade at } \\
9: 30 \text { a. m. }\end{array}$} \\
\hline & & Vol., C.c. & Sp. Gr. & Per Cent. & Gm. & & \\
\hline & & 95 & 1.019 & 0.35 & $\ldots$ & & \\
\hline & 0.092 & $\ldots$ & $\ldots$ & $\ldots$ & $\ldots$ & $\ldots$ & \\
\hline & 0.298 & $\cdots$ & $\ldots$ & & $\cdots$ & . & \\
\hline & & 80 & 1.020 & 0.60 & 0.48 & 0.32 & \\
\hline & $\begin{array}{l}0.241 \\
0.151\end{array}$ & $\dddot{88}$ & 1.016 & $\ddot{0} \ddot{9 i}$ & $\ddot{0} \ddot{80}$ & $\ddot{0.80}$ & \\
\hline & 0.096 & 167 & 1.011 & 0.32 & 0.54 & 0.54 & \\
\hline & 0.087 & 202 & 1.013 & 0.20 & 0.40 & 0.20 & \\
\hline
\end{tabular}

* Folin, O., and Wu, H.14

and a half hours and the normal level is reached again in three hours. The specimen of urine passed before the ingestion of glucose showed that sugar passed through the kidney with a blood concentration in the vicinity of 0.092 per cent. A previous determination had shown a glycosuria of 0.11 per cent. with a fasting bloud sugar of 0.068 per cent.; therefore, no question can be raised as to the extreme depression of the renal threshold.

In the course of ten months during which the glycosuria has been observed in hospital, there have been periods during which the patient

14. Folin, O., and Wu, H.: A System of Blood Analysis, Suppl. 1, J. Biol. Chem. 41:367 (March) 1920. 
has shown large changes in his body weight. A study of the fluid exchange and the rate of sugar excretion has shown no constant relation between the total fluid excreted and the amount of sugar in the urine. During one period there was a considerable fall in the sugar output with a retention of water, while during a subsequent period of diuresis the sugar showed no corresponding increase. This independence of sugar and fluid output has been noted in a majority of the published cases.

CASE 3.-C. M., (metabolism No. 56), aged 74; bookkeeper.

History.-This man was admitted on account of a severe attack of scurvy occasioned by a deficient diet, the result of his financial straits. The sugar was found during the routine analysis of the urine. Subsequent questioning failed to reveal any of the usual symptoms or signs of diabetes mellitus. There was no thirst; no craving for sweets; no polyuria; no loss of weight. Nothing suggesting hyperthyroidism, and beyond a mild eczema of the hands, he had been very healthy. The family history was negative as regards metabolic disorders.

Physical Examination.-Temperature, 98 F.; pulse, 80; respiration, 20 (on admission). A well nourished man; who appears much younger than stated age. There is fluid in both knee joints, and the right olecranon bursa is filled with blood-stained fluid. There are intramuscular hemorrhages in the thighs and calves of both legs. The gums are much cut up where several teeth have been extracted recently on account of "pyorrhea" and are quite spongy around the remaining teeth. The pupils react to light and accommodation. The chest shows a moderate emphysema and bronchitis. The heart is slightly enlarged, there is an extrasystolic arrhythmia, the sounds are well heard, and there is a soft apical systolic murmur. poorly transmitted to the axilla. The vessel walls are definitely thickened. Blood Pressure: 160/84. The abdomen is negative, the genitalia are negative.

Urine: Acid; specific gravity, 1.021; albumin, faint trace; sugar, 2.5 per cent. Acetone and diacetic acid are absent. Microscopic examination shows a few leukocytes and occasional hyalin and granular casts.

Tests of Kidney Function.-Blood urea, $0.435 \mathrm{gm}$. per liter; uric acid, $5 \mathrm{mg}$. per hundred c.c.; creatinin, $1.64 \mathrm{mg}$. per hundred c.c.; plasma chlorid, $6.19 \mathrm{gm}$. per liter. The nephritic test diet gives a normal curve, and the phthalein excretion is 64 per cent. in two hours.

Blood: Erythrocytes, 4,900,000; leukocytes, 7,200; hemoglobin, 90 per cent. (Talquist). Wassermann test negative.

Diagnosis.-(1) Scurvy, (2) arteriosclerosis and arteriosclerotic kidney, (3) glycosuria.

Diary.-The scurvy cleared up rapidly with the ordinary antiscorbutic foods, and the glycosuria was then studied. On ordinary diets with no limitation of carbohydrate he excreted from 33.2 to $53 \mathrm{gm}$. sugar daily, with a fasting blood sugar of 0.115 per cent., and a digestion sugar ${ }^{15}$ of 0.133 per cent. Four days of a low calory diet (protein, $43 \mathrm{gm}$; f fat, $46 \mathrm{gm}$., carbohydrate, $29 \mathrm{gm}$.), followed by starvation for two days and three days of protein $40 \mathrm{gm}$., only sufficed to reduce the daily sugar excretion to $15.6 \mathrm{gm}$. The attempt to render the urine sugar free was then abandoned. On subsequent days, with a

15. Blood taken one and one-half hours after food. 
gradually increasing diet, his output ranged from 20 to $57.5 \mathrm{gm}$. and the blood sugar from 0.112 to 0.129 per cent. when fasting, and from 0.121 to 0.161 per cent., one and half hours after food. In Table 6 a summary is presented of the diets, sugar excretion and bloud sugars, fasting and digestion, during his first admission.

This table shows the independence of carbohydrate intake and output. The highest excretion being immediately after the starvation period, when the intake was at its lowest level. Allen ${ }^{16}$ has directed attention to this apparent inability of the organism, be it normal or diabetic, to handle a sudden increase in the carbohydrate intake after a period of starvation or of low carbohydrate feeding. This also is

Table 6.-Summary of. Diet, Urine and Blood Sugar of C. M. (Case 3)

\begin{tabular}{|c|c|c|c|c|c|c|c|}
\hline \multirow{2}{*}{$\begin{array}{l}\text { Duration of } \\
\text { Period }\end{array}$} & \multicolumn{3}{|c|}{ Diet } & \multicolumn{2}{|c|}{ Urine Sugar } & \multicolumn{2}{|c|}{ Blood Sugar } \\
\hline & Protein & Fat & Carbohyd. & Per Cent. & Gm. & Fasting & Digestion \\
\hline & & House diet & & $2.2-3.8$ & $33.2-53.4$ & 0.115 & 0.133 \\
\hline 5 days & $0-40$ & 0 & 0 & $0.6-1.3$ & $16.0-23.1$ & 0.138 & 0.144 \\
\hline 12 days & 90 & 131 & 90 & $1.0-3.1$ & $20.3-5 i .5$ & 0.112 & 0.141 \\
\hline 8 days & 100 & 130 & 100 & $1.2-1.7$ & $22.3-38.1$ & 0.116 & 0.161 \\
\hline 5 days & 100 & 125 & 150 & $0.8-1.6$ & $28.7-39.0$ & 0.117 & 0.121 \\
\hline 4 days & 101 & 125 & 200 & $1.6-1.7$ & $25.3-48.8$ & 0.114 & 0.136 \\
\hline
\end{tabular}

TABLE 7.-Reaction of Sugar in Blood and Urine to Special Diets

\begin{tabular}{|c|c|c|c|c|c|c|c|}
\hline \multirow{2}{*}{$\begin{array}{l}\text { Duration of } \\
\text { Period }\end{array}$} & \multicolumn{3}{|c|}{ Diet } & \multicolumn{2}{|c|}{ Urine Sugar } & \multicolumn{2}{|c|}{ Blood Sugar* } \\
\hline & Protein & Fat & Carbohyd. & Per Cent. & $\mathrm{Gm}$ & Fasting & Digestion $†$ \\
\hline $\begin{array}{r}3 \text { days } \\
15 \text { days } \\
6 \text { days }\end{array}$ & $\begin{array}{c}80 \\
40-80\end{array}$ & $\begin{array}{c}\text { House di } \\
80 \\
0\end{array}$ & $\begin{array}{c}250 \\
0\end{array}$ & $\begin{array}{l}1.40-2.80 \\
0.90-2.80 \\
1.02-1.10\end{array}$ & $\begin{array}{l}30.1-33.3 \\
37.7-42.0 \\
17.4-20.7\end{array}$ & $\begin{array}{l}0.086 \\
0.088 \\
0.088 \\
0.046\end{array}$ & $\begin{array}{l}0.141 \\
0.136 \\
0.093\end{array}$ \\
\hline $\begin{array}{l}3 \text { days } \\
4 \text { days }\end{array}$ & $\begin{array}{l}0 \\
. \quad 80\end{array}$ & $\begin{array}{c}100 \\
80\end{array}$ & $\begin{array}{c}0 \\
250\end{array}$ & $\begin{array}{l}0.92-2.01 \\
1.60-5.40\end{array}$ & $\begin{array}{l}13.3-16.1 \\
37.5-54.0\end{array}$ & $\begin{array}{l}0.046 \\
0.078 \\
0.089\end{array}$ & $\begin{array}{l}0.061 \\
0.087 t \\
0.242\end{array}$ \\
\hline
\end{tabular}

shown in Table 7 , where the sudden change from a pure fat diet to a liberal régime containing $250 \mathrm{gm}$. of carbohydrate is associated with a marked digestion hyperglycemia (0.212 per cent.) and one of the highest sugar outputs (54 gm.) ever found in this case. During the second admission studies were made of the effects of high carbohydrate, high protein and high fat intakes, with the following results.

After a preliminary period the patient was given a fixed diet for fifteen days with increasing fluid intakes of $1,000,2,000,3,000$ and 4,000 c.c. per diem, but under these conditions the output showed only minor variations, an evidence of the lack of relation between the diuresis and the sugar leakage. With a pure protein dietary, there was a gradual drop in the blood sugar to the extremely low level of 0.046

16. Allen, F. M.. and Associates: Three Cases of "Renal Glycosuria," Arch. Int. Med. 24:523 (Nov.) 1919. 
per cent., but even on this day he excreted $19.42 \mathrm{gm}$. sugar. So far there had been no sign of acidosis, but on the third day of a pure fat diet he developed an alarming acid intoxication. The bicarbonate reserve dropped to 33 volumes per cent., and he became drowsy. The diet was changed at once to a more varied one, and in two days all sign of the acidosis had disappeared (bicarbonate reserve 60.5 volumes per cent.)

Response to Added Glucose.-Three blood sugar curves were carried out, in each case the usual dose of $100 \mathrm{gm}$. was given in lemonade.

TABle 8.-Response of Urine and Blood Sugar to 100 Gm. of Glucose.

\begin{tabular}{|c|c|c|c|c|c|c|}
\hline \multirow{2}{*}{$\begin{array}{c}\text { Hour } \\
\text { June } 16,1920\end{array}$} & \multirow{2}{*}{$\begin{array}{l}\text { Blood } \\
\text { Sugar }\end{array}$} & \multicolumn{4}{|c|}{ Urine } & \multirow[b]{2}{*}{ Remarks } \\
\hline & & Vol., C.c. & Per Cent. & Gm. • & Gm. per $\mathbf{H r}$ & \\
\hline \multirow{10}{*}{$\begin{array}{c}\text { 8:45 a.m. } \\
\text { 9:00 a.m. } \\
\text { 9:30 a.m. } \\
\text { 10:00 a.m. } \\
\text { 10:30 a.m. } \\
\text { 11:00 a.m. } \\
\text { 12:00 m. } \\
\text { 2:00 p.m. } \\
\text { 4:00 p.m. } \\
\text { 6:00 p.m. }\end{array}$} & 0.119 & $\ldots$ & 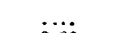 & $\ldots$ & $\ldots$ & \multirow{10}{*}{$\begin{array}{l}\text { Test taken a fter two days } \\
\text { of fasting and three of } \\
\text { earbohydrate-free diet } \\
100 \mathrm{gm} \text {. glucose at } 0: 00 \\
\text { a.m. }\end{array}$} \\
\hline & $\ddot{3} \cdot \dot{0}$ & $\ldots$ & 2.60 & $\ldots$ & $\ldots$ & \\
\hline & 0.200 & & $\cdots$ & & & \\
\hline & 0.200 & 85 & 2.17 & 1.85 & $1.8 \overline{5}$ & \\
\hline & 0.204 & $\ddot{0}$ & $\ldots$ & $\ddot{m}$ & $\ddot{\cdots}$ & \\
\hline & 0.200 & 125 & 3.08 & 3.78 & 3.78 & \\
\hline & 0.188 & 120 & 4.50 & 5.40 & 5.40 & \\
\hline & $* 0.150$ & 125 & 4.50 & 5.62 & 2.81 & \\
\hline & 0.138 & 125 & 2.70 & 3.37 & 1.18 & \\
\hline & 0.150 & 120 & 2.50 & 3.00 & 1.50 & \\
\hline \multirow{3}{*}{$\begin{array}{c}\text { March } 16,1921 \\
8: 45 \text { a.m. } \\
9: 00 \text { a.m. } \\
9: 30 \text { a.m. }\end{array}$} & & & & & & \\
\hline & 0.088 & $\ddot{8}$ & ï50 & $\cdots$ & $\cdots$ & \multirow{7}{*}{$\begin{array}{l}\text { After two weeks of pro } \\
\text { tein, } 80 \text { gm.; fat, } 80 \mathrm{gm} \text {.; } \\
\text { carbohydrate, } 250 \text { gm. } \\
100 \text { gm. glucose. at } 9: 00 \\
\text { a.m. }\end{array}$} \\
\hline & $\ddot{0} \ddot{1} 22$ & & 1.50 & $\cdots$ & $\cdots$ & \\
\hline 10:00 a.m. & 0.136 & 134 & 2.07 & 2.77 & 2.77 & \\
\hline $10: 30 \mathrm{a} . \mathrm{m}$. & 0.178 & & & & & \\
\hline 11:00 a.m. & 0.170 & 72 & 2.60 & 1.87 & 1.87 & \\
\hline 12:00 m. & 0.083 & 166 & 2.40 & 3.98 & 3.98 & \\
\hline \multirow{4}{*}{$\begin{array}{c}\text { March } 23,1921 \\
8: 45 \text { a.m. } \\
9: 00 \text { a.m. }\end{array}$} & 0.061 & 126 & 1.40 & 1.76 & 0.88 & \\
\hline & & & & & & \multirow{8}{*}{$\begin{array}{l}\text { After three days protein, } \\
40-80 \text { gm.; carbohydrate } \\
\text { free. } 100 \text { gm. glucose } \\
\text { at } 9: 00 \text { a.m. Voided at } \\
10: 15 \text { a.m. }\end{array}$} \\
\hline & 0.064 & 100 & 270 & $\cdots$ & $\cdots \cdot$ & \\
\hline & $\ddot{0.127}$ & $\begin{array}{l}150 \\
\ldots\end{array}$ & 2.60 & $\cdots$ & $\cdots$ & \\
\hline 10:00 a.m. & 0.192 & $\tilde{50}$ & 1.31 & 0.65 & 0.51 & \\
\hline 10:30 a.m. & 0.160 & $\ldots$ & $\cdots$ & $\cdots$ & $\cdots$ & \\
\hline 11:00 a.m. & 0.194 & $\ddot{\theta}$ & & & & \\
\hline $12: 00 \mathrm{~m}$ & 0.206 & 300 & 2.38 & 7.14 & 4.08 & \\
\hline 2:00 p.m. & 0.104 & 350 & 2.29 & 8.01 & 4.00 & \\
\hline
\end{tabular}

The second curve is the one most nearly approaching normal. The maximum rise in blood sugar is a little high and its appearance is slightly delayed, but this can be accounted for by the arteriosclerosis and low grade nephritis ${ }^{17}$ as shown by the albuminuria, casts, etc. The slow return to normal levels (three hours) can also be explained on the same grounds.

The first and third curves are decidedly abnormal, but are similar to those reported in other cases in which the test period was preceded by starvation or restricted carbohydrate intake. The fact remains, that in each case the kidney excretes sugar, while the glycemia is within normal limits, and in the third test the urine contained 2.7 per cent. sugar with a blood sugar of 0.064 per cent.

17. Janney, N.: Discussion, J. A. M. A. 75:217 (July 24) 1920. 
In this case the urine was collected in two hourly specimens during the day and a single specimen at night, and the hourly output was found to be remarkably constant. It was highest in the morning, fell during the afternoon and reached its lowest point during the night, showing in this regard a close resemblance to the output of albumin in that other anomaly of kidney action, orthostatic albuminuria.

TABLE 9--Rate of Sugar Excretion from Hour to Hour

\begin{tabular}{|c|c|c|c|c|c|c|}
\hline \multirow[b]{2}{*}{ March 7, 1921} & \multirow{2}{*}{$\begin{array}{l}\text { Volume } \\
\text { in C.c. }\end{array}$} & \multirow{2}{*}{$\begin{array}{l}\text { Specific } \\
\text { Gravity }\end{array}$} & \multicolumn{3}{|c|}{ Sugar } & \multirow{2}{*}{ r. Remarks } \\
\hline & & & Per Cent. & $\mathrm{Gm}^{\mathrm{Gm}}$ & Gm. per Hr & \\
\hline $\begin{aligned} \text { 8-10 a.m. } \\
10-12 \text { a.m. } \\
12-2 \text { p.m. } \\
\text { 2- } 4 \text { p.m. } \\
4-6 \text { p.m. } \\
6-8 \text { p.m. } \\
8 \text { p.m.-8 a.m. }\end{aligned}$ & $\begin{array}{r}95 \\
\mathbf{1 5 0} \\
335 \\
185 \\
155 \\
145 \\
1,050\end{array}$ & $\begin{array}{l}1.034 \\
1.030 \\
1.030 \\
1.028 \\
1.029 \\
1.030 \\
1.021\end{array}$ & $\begin{array}{l}4.59 \\
2.86 \\
1.74 \\
1.99 \\
2.02 \\
2.40 \\
1.36\end{array}$ & $\begin{array}{r}4.36 \\
4.29 \\
5.82 \\
3.68 \\
3.13 \\
3.48 \\
14.28\end{array}$ & $\begin{array}{l}2.18 \\
2.15 \\
2.91 \\
1.84 \\
1.54 \\
1.74 \\
1.19\end{array}$ & $\begin{array}{l}\text { Blood sugar: a. c., 0.104; } \\
\text { p. c., 0.134 } \\
\text { Diet: protein, } 80 \text { gm.; } \\
\text { fat, } 80 \mathrm{gm} . ; \text { carbohy } \\
\text { drate, } 250 \mathrm{gm} \text {. }\end{array}$ \\
\hline Total & 2,115 & & & 39.05 & & \\
\hline
\end{tabular}

SLMMARY

Notes are presented on three cases of renal glycosuria. The first patient, after six years of observation, still presents a marked glycosuria without symptoms and with a normal amount of sugar in the blood. $\mathrm{He}$ is apparently in excellent health.

The second is a severe case of chronic diffuse nephritis, in which a glycosuria appeared while under observation. The glycosuria has been practically continuous since its onset twelve months ago. It is small in amount, the largest quantity being $16 \mathrm{gm}$; it is largely independent of the carbohydrate intake, it requ1red three days starvation before its disappearance, and reappeared on an intake of $30 \mathrm{gm}$. carbohydrate as green vegetables. The amount of glucose does not show any constant relation to the urinary volume. Synchronous sugar determination on blood and urine show the presence of a glycosuria with 0.068 per cent. sugar in the blood. The response to $100 \mathrm{gm}$. glucose falls within the limits of a nondiabetic case of nephritis. There are no other signs of a diabetes mellitus.

The third patient, aged 74, has a marked arteriosclerosis, (arteriosclerotic kidney), and was first seen on account of scurvy. The duration of the glycosuria is unknown. The glycosuria has been continuous for the past fifteen months, the usual output varying from 30 to $50 \mathrm{gm}$., and the ordinary changes in the diet had very little effect on the amount of sugar excreted. The sugar output was found to be independent of the urine volume. Synchronous studies of the blood and urine showed 2.7 per cent. sugar in the urine, with only 0.064 per cent. in the blood. The blood sugar curve following ingestion of 100 gm. glucose is somewhat atypical, but can be explained by the presence of arteriosclerosis and nephritis. There are no signs of diabetes mellitus. 
It is generally recognized that there are two types of renal glycosuria ${ }^{17}$ : the one of unknown or idiopathic origin in which the blood sugar curve is of a strictly normal order, the other, is associated with a chronic diffuse nephritis or an arteriosclerosis, in which case the patient shows a remarkably high and prolonged rise in the blood sugar, which is probably a retention phenomenon, or may be connected with the high diastatic activity of the blood, so often seen in severe nephritis. The first case is an example of the idiopathic type, while the second and third are examples of the second group.

Acknowledgment is due to Dr. E. H. Mason who has kindly placed at my disposal much of the data connected with the second and third cases.; also to Miss Lane for technical assistance. 